\title{
The Influence of Corporate Branding Dimensions to Consumer's Product Evaluation: Cross-Cultural Perspective
}

\author{
Antonius Jan Wellyantony Putro \\ School of Business, Widya Mandala Catholic University, 42, Dinoyo, Surabaya, Indonesia
}

\begin{abstract}
Recently, the importance role of Corporate Brand were developed, as become a standard life style in global village life. Thousands of global brand indicate that the competition in branding strategy become more intensive. In order to achieving customer loyalty, a corporation has to do more effort to focusing their brand management with various corporate brand dimensions for any global citizenship with various cultural background. This research is aim to determine the influence of corporate branding to consumer's product evaluation with eastern and western cultural perspective to brand management. This research designed for survey method of the 350 respondents, with nonprobability samplings technique. Respondents were taken from Indonesian and the ex-patria tic. Meanwhile, SEM was used to analyze the model. The result of this research indicated that there is a positive influence between Corporate Brand Name, Corporate Images, Corporate Reputations, and Corporate Brand Loyalty to Consumer's Product Evaluation.
\end{abstract}

Keywords: Corporate brand name, Corporate images, Corporate reputations, Corporate brand loyalty, Consumer's product evaluation.

DOI: $10.7176 / \mathrm{EJBM} / 12-8-04$

Publication date:March $31^{\text {st }} 2020$

\section{Introduction}

Corporate brands can add value to the attractiveness of products in the eyes of consumers and play an important role in the decision of a company's product brand. The relationship between corporate and brand will have a beneficial impact on the copy and individual brands produced. The ability of Corporate Brands to reach consumers across countries requires a different approach from conventional brand strategies for local communities. This different approach can be illustrated by Van Gelder (2005) as Cultural Brand, Mind Share Branding, Emotional Branding, and Viral Branding. It was explained that, Cultural Branding is a more complex brand strategy to be handled, because it involves aspects of a deep understanding of consumer behavior of a country's consumers, ranging from tangibles to consumer preferences on the physical attributes of the product, namely shape, color, benefits, packaging, and marketing way.

Some multinational companies have an awareness of the importance of corporate names and always try to establish and create strong relationships between their corporate brands and product brands (Urde, 2003). The majority of these researchers only want to test some of the impact of corporate branding on evaluating product selection by consumers. Little research combines the relationship of the corporate branding dimension to the same study, or measures the interrelations between these dimensions, or further identifies the impact of these dimensions on consumer perception and evaluation. Furthermore, most studies have adopted theories of Western corporate branding and Western consumer perception and their impact on corporate brands. Therefore, this research is intended to explore different perspectives by incorporating Western's Corporate Branding and Eastern consumer theories.

\subsection{Prior Research}

Global Branding Strategy is a complex activity that requires the management of corporate companies to understand the internal and external factors that affect a brand if it is stretched across the world (Van Gelder, 2005: 40). The research found that global and international brands are influenced by structure, motivation, and culture across countries. Mooij and Hofstede (2010) in the Hofstede Model that examines the application of "Global Branding and Advertising Strategy and Research", explains the differences in brand strategy and advertising in various countries as a result of the nation's cultural dimension model, including differences in American and Japanese national brand strategy that contrasts representing differences in Western consumer behavior and Timur in terms of self concepts, personality, and identity (Mooij and Hofstede, 2010: 87).

In addition to his latest article, Urde (2003) states that the brand building process consists of two parts: internal and external. The definition of an internal process is a process that is mainly used to describe the relationship between an organization and a brand, with the organization's internal goal to bring the brand to life. While the external process, is related to the relationship between brands and customers, with external goals to create value and form relationships with customers. 


\subsection{Corporate Branding Strategy}

The contribution of corporate brands is not only to customer-based images, but also to images that are formed and held by all stakeholders including employees, customers, investors, suppliers, partners, regulators, special interests and local communities (Hatch and Schultz, 2008). The ability to use the company's vision and culture as part of a unique sales proposition is brought about by corporate branding in marketing (Hatch and Schultz, 2008). Balmer (2004) states that corporate brands have three important elements to be managed effectively, namely: values, promises and behavior. Hatch and Schultz (2008) also state that the success of corporate branding depends on a coherent relationship between strategic vision, organizational culture, and stockholders' image.

Van Riel and Bruggen (2002) define corporate branding strategy as a systematic planning and implementation process in creating and maintaining a favorable reputation. It was also stated that, corporate branding strategy are integrated elements that send signals to stakeholders, which implement the use of corporate brands. Several factors have an impact on crafting strategy for corporate brands.

\subsubsection{Difference between Western and Eastern Corporate Branding Theories}

has led to differences in understanding between researchers and practitioners about the impact of corporate branding on product evaluations by consumers (Mooij and Hofstede, 2010; 89). Researchers and practitioners from the West and East also have different opinions on this topic. Roll (2010: 170) states that there are differences in the Western and Eastern approaches to brands. Western theory of branding focuses more on the communication model, while Eastern theory of branding emphasizes the customer experience approach. This is because Western businesses tend to focus on developing sophisticated brand communication strategies without the need to place priority on adjusting the contents of the message being communicated. As a contradiction, instead of focusing on creating and communicating brand images, pursuing operational excellence is the priority and most important in the minds of Asian business leaders.

\subsubsection{Corporate Brand Name}

Keller (2008: 151) revealed that this would have an impact on the emergence of Corporate Brand Equity, which is when a constitution holds strong, unique, and likable associations in its mind relating to the brand of a corporation. Some factors that trigger the importance of corporate brand names are as follows: 1). Changes in the dynamics of Product Marketing, 2.) Wider sales channels, 3.)Diversified Communication Channels. 4.) The existence of mergers or other structural changes. 5.) Increased global activity. Hatch and Schultz (2008) suggested that the corporate brand foundation consists of three elements namely, strategic vision, organizational culture and corporate images. Vision explains the profile of the organization and the basic ideas of what it wants and what it wants to be like the organization.

\subsubsection{Corporate Images}

The second sub-construct related to the corporate paradigm is Corporate Images, which is a general impression in the public mind about companies (Barisch and Kotler, 1991: 97). Keller and Aaker (1997) report that a strong corporate image can be used to improve communication efficiency. Hsieh et.al (2004) concluded that corporate image can influence consumer behavior. Andreassen and Lindestad (2001) report that corporate image serves as an important factor influencing perceived quality, evaluating consumers' satisfaction and loyalty. In addition, The importance of corporate image is also reported in a study conducted by Bhattacharya and Sen (2003) who claim that a good corporate image is very helpful in making consumers increasingly committed to the company's products.

\subsubsection{Corporate Reputation}

Organizations increasingly recognize the importance of corporate reputation to achieve business goals and remain competitive. Corporate reputation has been tested as a factor that influences the company's financial performance (Dunbar and Schwalbach, 2000). Corporate reputation is also defined as the level of trust or distrust in the company's ability to meet customer expectations of certain product attributes (Nguyen and Leblanc, 2001). Corporate reputation is the value of attributes such as authenticity, honesty, responsibility and integrity that is reflected in the people who work at the company (Dowling, 2001: 19). Marketers believe that one of the main factors that has a strong impact on consumer purchasing decisions is consumers' perception of the role of companies in society and how companies treat stakeholders (Kowalczyk and Pawlish, 2002).

\subsubsection{Corporate Brand Loyalty}

Corporate loyalty can lead consumers towards loyalty to all company products (Bhattacharya and Sen, 2003). Loyalty is defined as a psychological statement of the results of individual perceptions, beliefs, and emotions that trigger the will or intention to develop and maintain a safe and long-lasting relationship (Iniesta, 2000: 179). The impact of loyalty on a company's business activities is found in several studies. Iniesta and Sanchez (2002) report that loyalty is the main goal of the majority of corporations because it can be utilized as a key strategic factor, such as market segmentation. Knowledge of consumer profiles at each level of loyalty will enable companies to design differentiated marketing programs that aim to maintain and increase loyalty or generate loyalty for consumers who are not loyal to the company (Iniesta and Sanchez, 2002). Further realization of the corporate brand has functioned as a direction that has full power for stakeholders for various purposes including investment, staffing, and especially for consumer buying behavior (Balmer and Gray, 2003:). 


\subsubsection{Relationship between variables}

Overall, the relationship between all variables, as well as proof of hypotheses in this study can be found a conceptual framework prepared by Hatch and Schultz (2001) that outlines the relevance of Corporate Brand Names with various important aspects of the organization as follows:

2.2.6.1. Relationship between Corporate Brand Name to Consumers 'Product Evaluation (H1), Consumers' Product Evaluation for Indonesian Citizens (H2), and Corporate Image (H3), and Relationships between Corporate Image of Consumers' Product Evaluation (H4), Consumers' Product Evaluation for Citizens Indonesia (H5).

Argenti (2004) who examined the relationship between Corporate Brand Name and Corporate Image, Corporate Reputation and Consumer Product Evaluation stated many things that explain the relevance and causes of these three related variables. The most important identity in a company is people's trust in the company's brand. The credibility of the company must be stated behind the corporate brand name. This means that the company's promises to the public and also customers must be fulfilled. Corporate Images and Corporate Reputations of the company as a trustworthy company will have an impact on corporate brand images Argenti (2004) (H3). Hatch and Schultz also (2001) state that, Corporate Brand Names not only contribute to the organization's customerbased images, but these images will also be formed and managed by all stakeholders, including. employees, customers, investors, suppliers, partners, regulators, special interests, and local communities $(\mathbf{H 3})$. The public will consider the basis of trustworthiness as stated by Argenti (2004) as the main factor in the selection of products or services or Consumer Product Evaluation (H4).

Argenti (2004) also explores that, Corporate Brand Name will also be increasingly seen as having more value if there is a uniqueness that characterizes corporate brands that distinguish them from competing brands. This characteristic comes from the personal characteristics of the individual who was the founder of the company. A strong, successful business personality helps shape the company's brand identity. Likewise, the individual founders of the company become branded separately representing Corporate Images and Corporate Reputation. The more liked this figure, the Corporate Brand Name also becomes more used as a choice, preference, and reference (H1).

Meanwhile, according to Roll (2010: 193), the people of Asia, especially Indonesia, which is still struggling with cultural issues in the political, financial and government sectors, have not been much concerned with global humanitarian and environmental issues. Therefore, Indonesian people choose products based on price sensitivity as the main factor in purchasing products or services. The dominance of cheap and competitive prices compared to these competitors has caused many Indonesian consumers to not consider Corporate Brand Name (H2).

Likewise, Corporate Images are not widely considered as a basis for product or service selection, due to the low price factor which is the main motivation for product purchases (Roll, 2010: 200). Indonesian society in general does not care who the person behind a successful brand or corporation is. For them it is sufficient that the product must be highly efficient and relatively low-priced. Brand promises as well as warranty and service are secondary factors after price. Even the safety of products or services for consumption is not too much thought. Therefore, for the people of Indonesia, Corporate Images and Corporate Reputation are also not considered as Consumer Product Evaluation (H5).

2.2.6.2. The relationship between Corporate Image and Corporate Reputation (H6), Corporate Brand Loyalty (H7), and Corporate Image as mediator of the Corporate Brand Name against Consumer's Product Evaluation (H8).

Some empirical evidence indicates that Corporate Images Benefit / Value is positively related to Corporate Brand Loyalty (Vazquez-Carrasco, and Foxall, 2006). Whereas corporate reputation is defined as the historical and cultural dimensions of corporate images, which contain the 'social memory' of stakeholders. A corporate reputation is created by stakeholders and becomes an organizational attribute (person or place), in response to their expectations of the organization (H6).

In their study, it was found that the benefits of Corporate Images consist of social benefits, confidence, and special treatment benefits, which have a direct influence on Corporate Brand Loyalty. In the context of the relationship found that consumer-salesperson relationship, Reynolds and Beatty (1999) found that when customers receive higher social benefits, then they become more loyal to salespersons, which then with continuous special treatment to these customers in the long run will create a Corporate Brand Loyalty $(\mathbf{H} 7)$.

Keller's theory (2008) states that attributes are "descriptive features" that characterize products or services. In this case, consumers consider several things about the product or service before making a purchase or consumption. The attributes considered can be classified into product-related attributes and non-product-related attributes (price, packaging, or product appearance information, user and usage imagery). Keller later described this as image benefits which can be classified as functional, experiential and symbolic benefits, as stated by Vazquez-Carrasco and Foxall (2006) above. Whereas symbolic benefits are associated with underlying needs for social approval or personal expression and outer-directed self-esteem, and are fundamentally related to non-products related attributes. From the description above shows that the Corporate Brand Name that is reflected by brand associations that are in the memories of consumers through several brand attributes, brand benefits, and overall brand attitudes 
can create image benefits in companies that consist of functional, experiential and symbolic benefits. And Keller (2008) further defines it above as brand attitudes, where consumers evaluate the total attributes of a brand or Consumer Product Evaluation (H8). Corporate Images can also increase value when helping customers process information, differentiate or differentiate the brand, provide considerations, provide positive feelings, and be the basis for brand expansion (Aaker, 2004) (H8).

2.2.6.3. The relationship between Corporate Reputation and Corporate Brand Loyalty (H9), Consumers' Product Evaluation (H10), and Consumers' Product Evaluation for Citizens Indonesia (H11), and the Relationship between Corporate Brands Loyalty towards Consumers' Product Evaluation (H13), Consumers' Product Evaluation for Citizens Indonesia (H14), and Corporate Brand Loyalty as mediator of the Corporate Reputation of Consumers Product Evaluation (H16).

The relationship between Corporate Reputation and Corporate Brand Loyalty can be easily found in the relationship that exists between the company and its customers. This positive reputation that lasts long in the minds of customers raises the tendency of customers to be reluctant to switch to other brand products or services. The existence of additional value compared to other brands, makes customers have Corporate Brand Loyalty in certain brands which are perceived as the brands that provide the most benefits among other brands (H10). The tendency of customers to choose brands with the highest functional and financial benefits makes them always make that brand a priority in evaluating product purchases or Consumer Product Evaluation (H13). Based on the description above and clearly seen that Corporate Reputation raises Corporate Brand Loyalty, which then creates Consumer Product Evaluation. Thus, Corporate Brand Loyalty is a mediator of Corporate Reputation on Consumer Product Evaluation (H16).

Indonesian people who tend to have homogenous regional and collectivist behavior do not question the issue of corporate reputation as important (Roll, 2010: 190). Even the Indonesian people do not feel the need to know what is behind a corporate name. The current state and development of corporate reputation is not unattractive to be listened to and discussed in the daily conversation of the public through news in various media. Therefore, Corporate Reputation has no impact on Consumer Product Evaluation for the people of Indonesia (H11).

Another thing that happens for Indonesian people is a culture of following trends and silos activities that can create conditions where the community is loyal to certain corporate brands (Roll, 2010: 212). Whatever is the center of the issue at any given moment, encourages the speed of purchasing decisions on certain products or services. Indonesian society is dominated by emotional factors as the basis for purchasing products (Roll, 2010: 217), so it's easy to switch and change brands. Therefore, Corporate Brand Loyalty is not an important factor as a Consumer Product Evaluation consideration for Indonesian people (H14).

2.2.6.4. Relationship of Corporate Reputation as mediator of Corporate Images of Consumer's Product Evaluation (H12).

Keller (2008) then states that, in consideration of product or brand selection (Consumer's Product Evaluation), consumers or customers will associate each level of these attributes with certain brand products with the company that made them (H12). Like a high quality association, it raises the perception that the company that makes products is a high quality company and produces products, and so on for each of the associate attributes above.

2.2.6.5. Relationship of Corporate Brand Loyalty as mediator of Corporate Images to Consumer's Product Evaluation (H15).

The success of corporate branding loyalties requires corporate images which are also related to organizational corporate branding culture which then becomes the basis for values in every day's organizational behavior. Corporate projects to create corporate images in achieving corporate brand loyalty must step into the company's organizational culture (beliefs, meanings, stories and other symbolic sources that express unique sense-making and sense-giving patterns that only companies have) that aim to create brand promises that provide resonance with the actual brand experience offered by members of the organization as a basis for product purchasing decision or consumer's product evaluation (H15). 


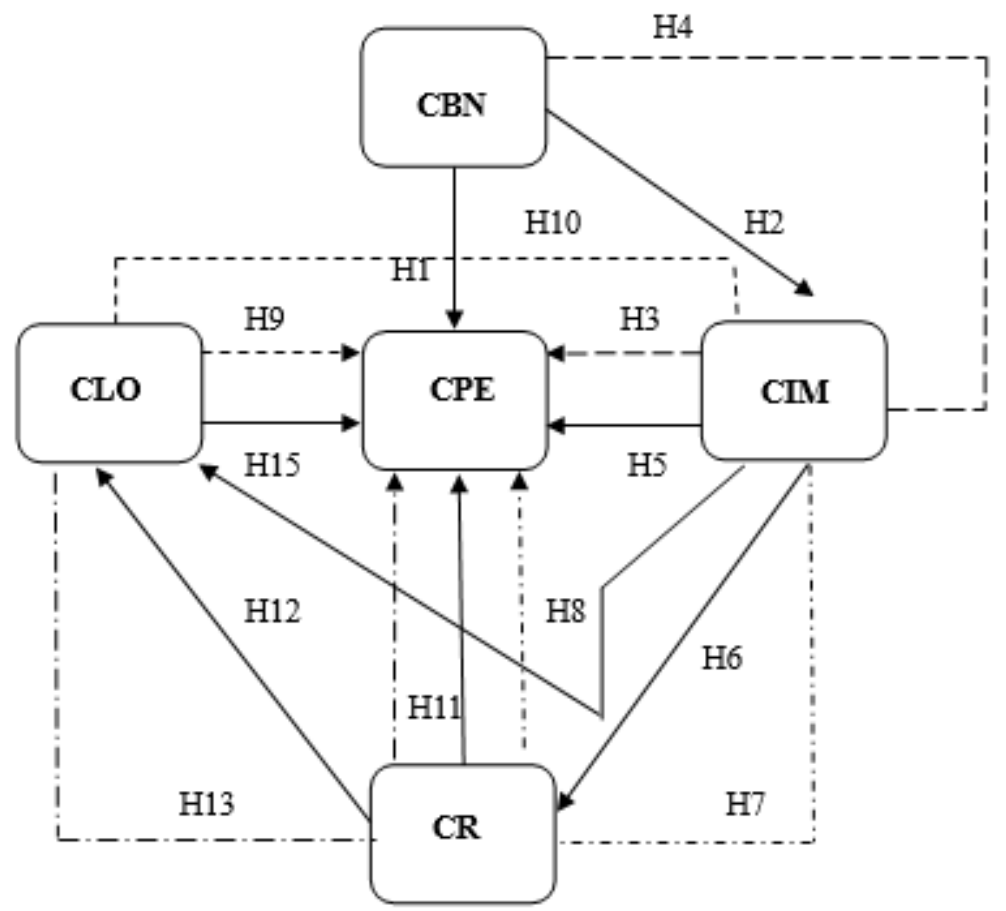

Figure 2.1. Conceptual Framework Source: data processed.

\section{Research Method}

This causal study analyzes the effect of Corporate Brand Name, Corporate Images, Corporate Reputation and Corporate Brand Loyalty on Consumer's Product Evaluation, which is conducted in the form of a survey. Explanatory research is applied to explain the relationship between variables, both direct relationships and mediation relationships. Model Structure Analysis and Research Hypotheses are proven by SEM, on AMOS SPSS. The research population is Indonesian citizens who have lived in Japan or America for more than 5 years, because Brand Knowledge in both countries is needed to be able to answer research instruments correctly. The NonProbability Sampling technique was chosen, in order to obtain respondents in accordance with the research construct. Purposive Sampling, applied to get the best respondents This data was obtained through a questionnaire that was distributed and filled out by 350 respondents.

\section{Data analysis \& Discussion}

The influence between variables in this study can be demonstrated by the value of R Square on each relationship between variables. Based on the results in table 4.1. ,

Table 4.1. Coefficient of Determination of Research Variables Summary Model

\begin{tabular}{|c|c|c|c|c|c|}
\hline Model & R & R Square & Adjusted R Square & Std. Error of the Estimate & Durbin Watson \\
\hline 1 & .96 & .921 & .920 & 12.910 & 1.488 \\
\hline
\end{tabular}

Source : Appendix 8, data processed.

which represents an explanation of one of the relationships between variables, it is known that the relationship has an R Square value of 0.921 . This value indicates that the corporate brand name variable can explain the variation of data on the consumer product evaluation variable of $92.1 \%$. While other variables not analyzed in this model are $7.9 \%$.

Table 4.2 shows the $F$ test results, A statistical $F$ value of 1141,468 indicates that this research model matches the data obtained, on the basis of a probability value of 0,000 . With a probability value of $0,000<0.001$, the research model is categorized fit with the data. VIF value of 1.00 which is smaller than 10 indicates that in this research model there is no multi collinear relationship between independent variables.

Table 4.2. Hypothesis Testing Through F Test ANOVA

\begin{tabular}{|l|l|l|l|l|l|}
\hline \multicolumn{1}{|c|}{ Model } & \multicolumn{1}{|c|}{ Sum of Squares } & \multicolumn{1}{c|}{ Df } & Mean Square & F & Sig. \\
\hline Rregression & 190248.4 & 1 & 190248.443 & 1141.468 & .000 \\
Residual & 16333.397 & 98 & & & \\
Total & 206581.8 & 99 & & & \\
\hline
\end{tabular}

Source : Appendix 8, data processed. 
Table 4.3. Hypothesis Testing Through F Test

\begin{tabular}{|c|c|c|c|c|c|c|c|}
\hline \multicolumn{8}{|c|}{ Coefficient } \\
\hline Model & \multicolumn{2}{|c|}{$\begin{array}{l}\text { Unstandardized } \\
\text { Coefficient }\end{array}$} & Standardized Coefficient & $\mathrm{t}$ & Sig. & \multicolumn{2}{|c|}{ Collinearity Statistics } \\
\hline Constant & 2.196 & 2.097 & \multirow[t]{2}{*}{960} & 1.047 & .298 & Tolerance & VIF \\
\hline $\mathrm{CBN}$ & .961 & .028 & & 33.786 & .000 & 1.00 & 1.00 \\
\hline
\end{tabular}

Source : Appendix 8, data processed.

Table 4.4. Hypothesis Test

\begin{tabular}{|c|c|c|c|c|c|}
\hline Test & Variable & Estimate & $\begin{array}{c}\mathrm{t}- \\
\text { Value }\end{array}$ & Sig. & Explant \\
\hline $\mathrm{H}_{1}$ & $\begin{array}{l}\text { Corporate Brand Name, } \\
\text { Consumer Product Evaluation }\end{array}$ & .960 & 33.786 & 0.000 & $\begin{array}{l}\mathrm{H}_{0} \text { Rejected } \\
\mathrm{H}_{1} \text { Excepted }\end{array}$ \\
\hline $\mathrm{H}_{2}$ & $\begin{array}{l}\text { Corporate Brand Name, } \\
\text { Consumer Product Evaluation WNI }\end{array}$ & .857 & 16.441 & 0.000 & $\begin{array}{l}\mathrm{H}_{0} \text { Rejected } \\
\mathrm{H}_{1} \text { Excepted }\end{array}$ \\
\hline $\mathrm{H}_{3}$ & $\begin{array}{l}\text { Corporate Brand Name, } \\
\text { Corporate Image. }\end{array}$ & .848 & 15.852 & 0.000 & $\begin{array}{l}\mathrm{H}_{0} \text { Rejected } \\
\mathrm{H}_{1} \text { Excepted }\end{array}$ \\
\hline $\mathrm{H}_{4}$ & $\begin{array}{l}\text { Corporate Images, } \\
\text { Consumer Product Evaluation }\end{array}$ & .980 & 48.554 & 0.000 & $\begin{array}{l}\mathrm{H}_{0} \text { Rejected } \\
\mathrm{H}_{1} \text { Excepted }\end{array}$ \\
\hline $\mathrm{H}_{5}$ & $\begin{array}{l}\text { Corporate Images, } \\
\text { Consumer Product Evaluation WNI }\end{array}$ & .470 & 5.275 & 0.000 & $\begin{array}{l}\mathrm{H}_{0} \text { Rejected } \\
\mathrm{H}_{1} \text { Excepted }\end{array}$ \\
\hline $\mathrm{H}_{6}$ & $\begin{array}{l}\text { Corporate Images, } \\
\text { Corporate Reputation }\end{array}$ & .941 & 27.510 & 0.000 & $\begin{array}{l}\mathrm{H}_{0} \text { Rejected } \\
\mathrm{H}_{1} \text { Excepted }\end{array}$ \\
\hline $\mathrm{H}_{7}$ & $\begin{array}{l}\text { Corporate Images, } \\
\text { Corporate Brand Loyalty }\end{array}$ & .888 & 19.068 & 0.000 & $\begin{array}{l}\mathrm{H}_{0} \text { Rejected } \\
\mathrm{H}_{1} \text { Excepted }\end{array}$ \\
\hline $\mathrm{H}_{8}$ & $\begin{array}{l}\text { Corporate Brand Name, } \\
\text { Corporate Images, } \\
\text { Consumer Product Evaluation }\end{array}$ & .828 & 64.406 & 0.000 & $\begin{array}{l}\mathrm{H}_{0} \text { Rejected } \\
\mathrm{H}_{1} \text { Excepted }\end{array}$ \\
\hline $\mathrm{H}_{9}$ & $\begin{array}{l}\text { Corporate Reputations, } \\
\text { Corporate Brand Loyalty }\end{array}$ & .859 & 16.614 & 0.000 & $\begin{array}{l}\mathrm{H}_{0} \text { Rejected } \\
\mathrm{H}_{1} \text { Excepted }\end{array}$ \\
\hline $\mathrm{H}_{10}$ & $\begin{array}{l}\text { Corporate Reputaions, } \\
\text { Consumer Product Evaluation }\end{array}$ & .742 & 10.950 & 0.000 & $\begin{array}{l}\mathrm{H}_{0} \text { Rejected } \\
\mathrm{H}_{1} \text { Excepted }\end{array}$ \\
\hline $\mathrm{H}_{11}$ & $\begin{array}{l}\text { Corporate Reputaions, } \\
\text { Consumer Product Evaluation WNI }\end{array}$ & .563 & 6.740 & 0.000 & $\begin{array}{l}\mathrm{H}_{0} \text { Rejected } \\
\mathrm{H}_{1} \text { Excepted }\end{array}$ \\
\hline $\mathrm{H}_{12}$ & $\begin{array}{l}\text { Corporate Images, } \\
\text { Corporate Reputations, } \\
\text { Consumer Product Evaluation }\end{array}$ & .683 & 38.460 & 0.000 & $\begin{array}{l}\mathrm{H}_{0} \text { Rejected } \\
\mathrm{H}_{1} \text { Excepted }\end{array}$ \\
\hline $\mathrm{H}_{13}$ & $\begin{array}{l}\text { Corporate Brand Loyalty, } \\
\text { Consumer Product Evaluation }\end{array}$ & .906 & 21.021 & 0.000 & $\begin{array}{l}\mathrm{H}_{0} \text { Rejected } \\
\mathrm{H}_{1} \text { Excepted }\end{array}$ \\
\hline $\mathrm{H}_{14}$ & $\begin{array}{l}\text { Corporate Brand Loyalty Consumer Product Evaluation } \\
\text { WNI }\end{array}$ & .369 & 3.926 & 0.000 & $\begin{array}{l}\mathrm{H}_{0} \text { Rejected } \\
\mathrm{H}_{1} \text { Excepted }\end{array}$ \\
\hline $\mathrm{H}_{15}$ & $\begin{array}{l}\text { Corporate Images, } \\
\text { Corporate Brand Loyalty, } \\
\text { Consumer Product Evaluation }\end{array}$ & .794 & 40.089 & 0.000 & $\begin{array}{l}\mathrm{H}_{0} \text { Rejected } \\
\mathrm{H}_{1} \text { Excepted }\end{array}$ \\
\hline $\mathrm{H}_{16}$ & $\begin{array}{l}\text { Corporate Reputation, } \\
\text { Corporate Brand Loyalty, } \\
\text { Consumer Product Evaluation }\end{array}$ & .765 & 37.635 & 0.000 & $\begin{array}{l}\mathrm{H}_{0} \text { Rejected } \\
\mathrm{H}_{1} \text { Excepted }\end{array}$ \\
\hline
\end{tabular}

Source : Appendix 8, data processed.

The following table 4.4 is used to indicate the acceptance of the hypothesis in this study. Explanation of the results of the hypothesis test in this study is based on the Probability Value and t-Value, which determine the positive or negative influence of the relationship between the variables in the observed study: Evidence of hypothesis testing, which is contained in Table 4.4. can be analyzed that all variable with a Probability Value $<0.001$, and an Estimated Value of $>0.001$, and a t-Value of $>1$ indicates that all $\mathrm{H} 0$ is rejected and all $\mathrm{H} 1$ is accepted.

Tests based on the statistics mentioned above will be supplemented by the meaning of each output of the relationship test results for each variable examined in this study. The following discussion is a manifestation of the results in the form of numbers generated in the various results previously described : 
H1. Corporate Brand Name has an influence on Consumer Product Evaluation, where in the era of global villages such as in 2012, brand names are closely related to civilization of the world community who always assume that brand names reflect the identity of the wearer. Prestige consumers who are reflected in the selection of brand names, are important things that can put the reputation of individual users at risk. Consumer evaluation of brands has become an integral part of the user's personality. The brand is the second dress that makes the person who wears it increases in terms of value both visually and functionally by the surrounding environment. By evaluating the right brand to be chosen, then consumers as individuals expect to be accepted by other individuals, and also by the environment that has certain lifestyle standards demands.

H2. Corporate Brand Name has an influence on Consumer Product Evaluation for Indonesian Citizens, which is because Indonesia as a developing country has become the largest market area for products or brands from various developed countries. Developing countries like Indonesia, which has a very dense population, is a potential market share than countries with smaller populations. On the other hand, the needs of Indonesian citizens (especially those who have lived a long time outside Indonesia) to be aligned with the level of life of their citizens with other countries that have advanced, making them tend to consume the global corporate brand as a necessity. Positioning from global corporate brand is expected to boost the individual reputation of Indonesian consumers who are not inferior in global competitiveness as universal demands.

H3. Corporate Brand Name has an influence on Corporate Images, which shows the achievements of the corporation in its brand strategy. With a Corporate Brand Name that is able to accommodate Corporate Images, the company has successfully managed one of its other valuable assets, the brand. The brand is a communication tool for the company to its customers. Such a brand can bring a company to a competitive advantage with a cost that is more efficient than other tangible assets such as technology and corporate buildings.

H4. Corporate Images affect Consumer Product Evaluation, is a condition in which consumers are well aware that a corporate image also carries a certain self image of consumers as individuals. Consumers who are faced with a variety of brand choices will tend to evaluate these brands to be selected in accordance with the desired image output criteria. Thus, corporate image is a selection tool that cannot be separated from product evaluation by consumers.

H5. Corporate Images affect Consumer Product Evaluation for Indonesian Citizens, which is the specific form of influence in this case, where Indonesian consumers tend to associate corporate images with the country of origin effect with the countries producing global brands. Indonesian consumers have a stereotype of certain views on the countries producing various products that are circulating in Indonesia. The evaluation of brand selection here tends to be based on the positive and negative country of image behind the brand name of the corporation. In evaluating products, Indonesian consumers have priority to find information on the country of origin of a brand, which is then followed by a corporate image.

H6. Corporate Images affect the Corporate Reputation, as has been suggested from the theory previously described that, corporate images will create long-lasting positioning in the minds of customers in the form of corporate reputation. The corporate reputation is related to the credibility and accountability of the corporation, especially on sensitive humanism and justice issues, which are 'captured' by consumers from corporate social responsibility. Brand evaluation by consumers can be disturbed by the presence of disturbing issues.

H7. Corporate Images affect the Corporate Brand Loyalty, which is raised because of the compatibility between certain corporate images with the needs and desires of individual consumers. The daily activities of consumers depend on the attractiveness of corporate images owned by a brand. These Corporate Images have become the needs of consumers as part of their lives. Consumers do not want to let go of that image, which results in it being loyal to one or several corporate brands.

H8. Corporate Brand Name, through Corporate Images affects Consumer Product Evaluation. This shows that there is actually a chain of links between the three variables. From the explanations described above it can be understood that the corporate brand name reflects certain corporate images. By choosing corporate brand names, symbols, dominant colors, symbols, and the shape of a brand, will create certain meanings and meanings perceived by consumers. Perceived value owned by consumers towards the brand to form corporate images. Adjustment of perceived value with the needs and wants of consumers, making it an evaluation of the product that will be used. H9. Corporate Reputations affect the Corporate Brand Loyalty, a condition where the corporate reputation of word of mouth between consumers will determine the selection of brands to be consumed. In addition, the percentage of positive information on corporate reputation from various media sources also plays a role in limiting alternative brands to be chosen. Corporate Brand Loyalty tends to be more owned by corporations that have a high sense of humanism, as a form of consumer sympathy for caring companies.

H10. Corporate Reputations affect Consumer Product Evaluation. The list of corporation companies that have a positive reputation among the wider community has become a general guide for consumers in choosing the product that they will decide to buy. Dislike for a particular corporation because of something that offends the general humanity side, will make consumers refuse to consider the corporation's corporate brand in its list of brands.

H11. Corporate Reputations affect Consumer Product Evaluation for Indonesian Citizens. Indonesian consumers 
with Eastern culture have a higher sensitivity to the values of humanism, even positioning it as a culture or procedure for daily living. These consumers respond more to issues related to humanism or the environment as emotional. They more quickly exclude a list of brands with a background of negative corporate reputation from their product evaluation list, so that corporate reputation has an influence in the form of high sensitivity to consumer product evaluation for Indonesian citizens.

H12. Corporate Images, through Corporate Reputations affect Consumer Product Evaluation. A product with brand design that is managed optimally to focus on customer-oriented, will be able to produce superior appeal in the eyes of customers and prospective customers. This brand appeal in the short term creates more corporate images than other brands. Whereas in the long run, brand appeal is able to leave its mark in the form of brand awareness in the minds of consumers as corporate reputation. When evaluating products, these brands are the first to be considered.

H13. Corporate Brand Loyalty influences Consumer Product Evaluation. Consumers who are loyal to a particular corporate brand are based on the specifications of their needs and desires that have been well fulfilled. Consumers tend to be reluctant to exchange or trial errors for new products, which will sacrifice the percentage of satisfaction level for certain brands that have been used. Consumers also do not want to lose the efficiency and effectiveness it gets from products that have long been used, by issuing opportunity costs.

H14. Corporate Brand Loyalty influences Consumer Product Evaluation for Indonesian Citizens. Family factors are the dominant factor for Indonesian consumers to evaluate products and brands. Without family consideration, Indonesian consumers are less able to make unanimous buying decisions. Brands that have been used by families for generations, passed down from generation to generation are also forms typical corporate brand loyalty in Indonesia. However, any decision about the product or brand always makes the brand name that is used by the family as the first choice in product evaluation for Indonesian consumers.

H15. Corporate Images, through Corporate Brand Loyalty influence on Consumer Product Evaluation. Corporate Images with a high degree of adaptation available dap consumer tastes and consumer preferences that vary according to prevailing lifestyles, serve as the glue between corporate brand loyalty to consumer product evaluation. Corporate Images like this are able to keep consumers so that consumers do not need to switch to other brands, so they no longer need to consider or evaluate other products.

H16. Corporate Reputations through Corporate Brand Loyalty influence Consumer Product Evaluation. Corporate reputation that impresses the hearts of consumers will make the products of the corporation always the first choice for considered and consumed. Corporate reputation is also a perceived value that is accepted as part of a consumer's life-style, which will reflect his reputation as an individual with unique personality traits, no one likes it. As long as there are no other corporations that are able to provide more fulfill the expectation of the brand that has been used so far, consumers will remain loyal to this corporate brand, and make this brand as the first option in evaluating various products

\section{Suggestion}

1. Companies must pay attention to Corporate Branding. This is because a strong Corporate Brand functions as an important asset of the company, especially in a competitive environment where customers, investors, and employees are faced with many strategic choices. With the increasing market share and the company's products, a strong Corporate Brand will be an attraction for the next product and also the company's future.

2. The company must focus on Corporate Brand management as Corporate Reputation management. Developing and communicating Corporate Brand, can significantly control the company's business decisions remain on the path towards achieving the company's strategy. Corporate Brand, creating expectations in the minds of customers that will be met by the company in the form of images in accordance with the wishes of the company, which in turn will form a certain reputation on the corporation.

3. The development of Corporate Brand management and Corporate Reputation management generates business opportunities. This opportunity is created by connecting the company's strategy and vision to the marketing and communication functions of the company, which can offer financial benefits. Companies that can manage Corporate Brand and Corporate Reputation can make a difference to companies in a competitive environment.

4. Corporations can make efforts to build and improve brand loyalty in the minds of customers in a number of ways. With competitive market conditions, companies must treat customers as friends. To achieve this goal, managers must use information search groups in the field, brand representations, and brand ambassadors. The ways to build customer loyalty are as follows:

a. Establish customer care, where companies must think of many ways to be able to recognize their customers as much as possible. By asking a series of open-mind questions, corporations can talk more about the situation of the customers they face.

b. Honesty of the company to customers, which has a long-term impact on customer trust needs to be sought. Fair treatment will greatly assist a corporation in gaining the confidence of its customers.

c. Measured loyalty enables corporations to see clearly the level of customer loyalty. Generally, customers are 
divided into 3 groups according to the criteria they collect from various information in the field. If customers get a score of 1-6, then this means that it is categorized as detractors. Passive customers are those who have a score of $7-8$, and promoters customers are able to reach a score of 9-10. Furthermore, the score is divided by the total number of customers who took part in this test with promoters. Percentages that represent the level of customer loyalty are obtained this way. The majority of companies generally have 10-20\% loyal customers.

\section{References}

Aaker, D.A. (2004). Leveraging the Corporate Brand, California Management Review, 46 (3).

Alessandri, S.W. (2001). Modelling Corporate Identity; A Concept Explication and Theoritical Explanation, Corporate Communication, Volume 6.

An Asia Business Council Workshop, Branding in Asia, 2005.

Andreassen, T.W. Lindestad, B. (2001). Customer Loyalty and Complex Service, International Journal of Service Industry Management, Volume 9.

Argenti, Paul A. (2004). Reputation and Corporate Brand, Corporate Reputation Review, Volume 6, Number 4, The Tuck School of Business. USA.

Balmer, John, M.T. (2004). The Corporate Branding Triumvarite: Values, Promise and Behavior?, Working Paper Series No 04/31.

Balmer, John, M.T. dan Gray, Edmund (2003). R. Corporate Brands: What Are They? What of Them?, European Journal of Marketing, 37 (7/8).

Barisch, H. Kotler, P. (1991). A Framework of Marketing Images Management, Sloan Management Review, Volume 32.

Bhattacharya, C.B. Sen, S. (2003). Consumer-Company Identification: A Framework for Understanding Consumer's Relationship with Companies, Journal Of Marketing, Volume 67.

Dowling, G.R. (2001). Creating Corporate Reputations,Identity Image, and Performance, Oxford University Press, Oxford.

Dunbar, RLM. dan Schwalbach, J. (2000), Corporate Reputation and Performance in Germany, Corporate Reputation Review, 3(2) April.

Hatch, M.J. dan Schultz, M. (2008). Taking Brand Initiative: How Companies Can Align Strategy, Culture, and Identity through Corporate Branding?, Jossey-Bass.

Iniesta, M.A. (2000). Commitment in Consumer-Retail Exchange Relationship, Unpublished Thesis, University of Almeria, Almeria.

Iniesta, M.A. Sanchez, M. (2002). Retail-Consumer Commitment and Market Segmentation, International Review of Retail, Volume 12.

Keller, Kevin Lane. dan Aaker, David. (1997). Managing The Corporate Brand: The Effect of Corporate Marketing Activity on Consumer Evaluations of Brand Extension, Working Paper report, Marketing Science Institute, Cambridge, Mei.

Keller, Kevin Lane., (2008). Strategic Brand Management, 3rd ed, Prentice Hall, Upper Saddle River, NJ.

Kowalczyk, SJ., dan Pawlish, MJ. (2002).Corporate Branding through External Perception of Organizational Culture, Corporate Reputation Review, Volume 5, November.

Mooij, Marieke. dan Hofstede, (2010). Geert. The Hofstede Model: Application to Global Branding and Advertising Strategy and Research, International Journal of Advertising, Advertising Association Publisd.

Nguyen. N. Leblanc, G. (2001). Corporate Images and Corporate Reputation in Customers, Journal of Retailing and Consumer Service, Volume 8.

Reynolds, Reynolds, K. E., \& Beatty, S. E. (1999).Customer benefits and company consequences of customersalesperson relationships in retailing, Journal of Retailing, 75(1).

Roll, Martin. (2010). Asian Branding Strategy: How Asia Builds Strong Brands, Design Management Journal, Volume 12.

Urde, (2003). Mats. Core Value-Based Corporate Brand Building, European Journal of Marketing, 37 (7/8)

Van Gelder, Sicso. (2005).Unlocking Brand Potential Across Countries, Cultures and Markets: Toward The Nation's Brand, Kogan Page, London, UK.

Van Riel, C.B.M. dan Van Bruggen, G.H. , (2002). Incorporating Business Unit Managers' perspectives in corporate-branding strategy decision making. Corporate Reputation Review, 5(2-3).

Vazquez-Carrasco, R. dan Foxall, G. R. (2006) Influence of personality traits on satisfaction, perception of relational benefits, and loyalty in a personal services context, Journal of Retailing and Consumer Services, 13(3). 


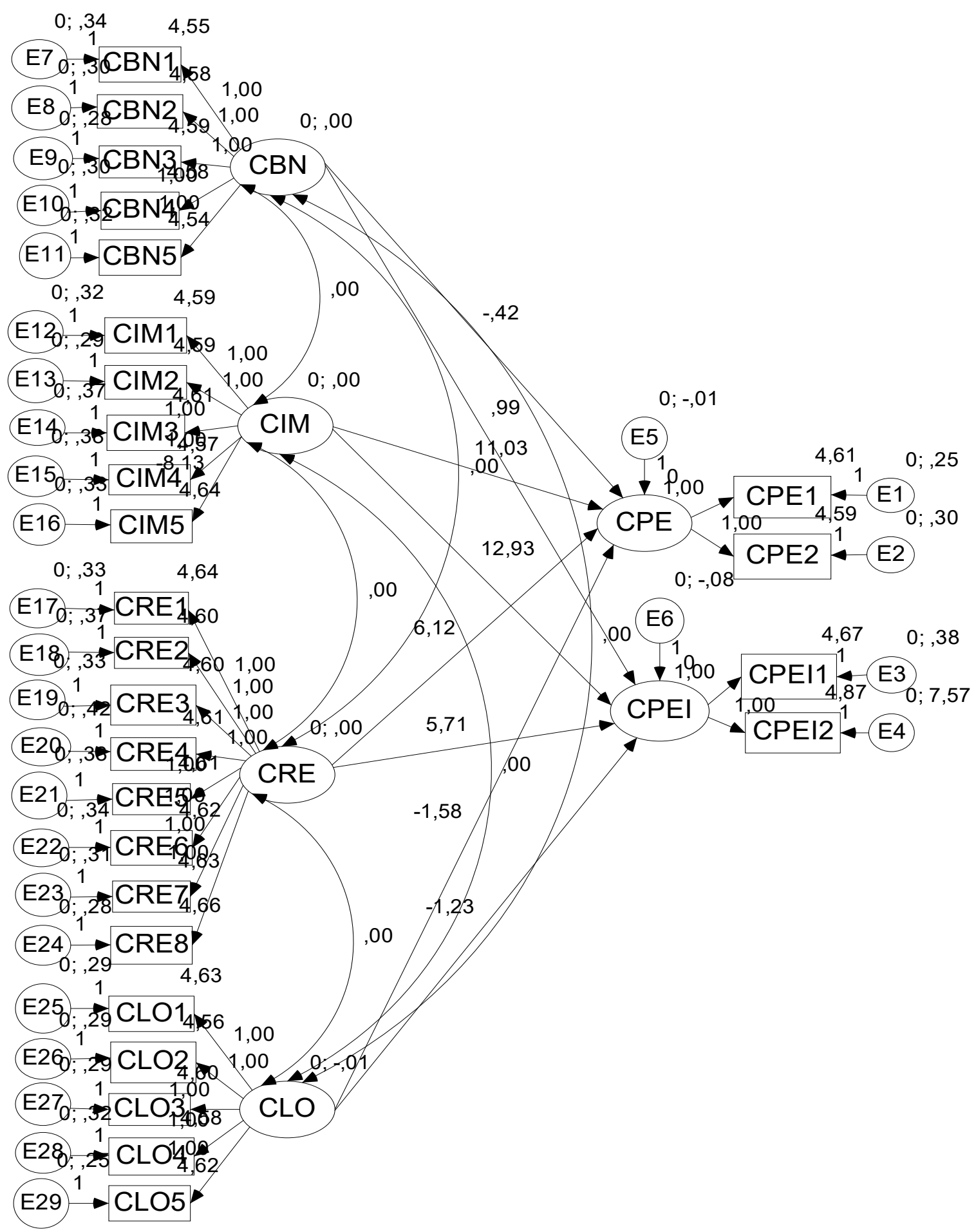

Figure 4.1.

Path value for each path

Source: Data processed. 